\title{
Assessment of residential satisfaction in newly designed public low-cost housing in Kuala Lumpur, Malaysia
}

\author{
Mohammad Abdul Mohit*, Mansor Ibrahim, Yong Razidah Rashid \\ Kulliyyah of Architecture and Environmental Design, IIUM, Gombak, 53100 Kuala Lumpur, Malaysia
}

Keywords:

Public low-cost housing

Residential satisfaction

Dwelling unit features

Socio-economic characteristics

Public facilities

Social environment

Neighbourhood facilities

\begin{abstract}
A B S T R A C T
This paper provides an assessment of residential satisfaction of newly designed public low-cost housing dwellers of Kuala Lumpur, Malaysia, with forty-five variables grouped into five components - dwelling unit features, dwelling unit support services, public facilities, social environment and neighbourhood facilities. Findings from the study indicate that the residents are moderately satisfied with dwelling unit support services, followed by public and neighbourhood facilities than dwelling unit features and social environment, which have higher percentage of respondents with low level of satisfaction. Residential satisfaction index has high positive correlations with dwelling unit features, social environment, support services and public facilities, and low positive correlation with neighbourhood facilities. Socio-economic attributes of the residents such as age, family size, working wives, previous residence are negatively correlated with residential satisfaction, whereas residents' race, employment type, floor level and length of residency are positively correlated with residential satisfaction. A Multiple Linear Regression (MLR) model has been estimated for the study and the model provides $76 \%$ explanations to determine residential satisfaction with ten predictor variables. The high beta coefficients of the model suggest that residential satisfaction of public low-cost housing can be enhanced through improving the management of security control, perimeter roads, cleanliness of garbage house and garbage collection, by the Local authority (KLCH). Moderate beta coefficient values of the model suggest that improvement of housing design is necessary to enhance residents' satisfaction with the predictor variables such as dry area, bedroom-1, dinning space, socket points and bedroom-3. From socio-economic analysis, it was found that the size of existing low-cost unit does not satisfy the needs of $29.4 \%$ inhabitants with large (6+) families and high bedroom occupancy rates (2.5). Furthermore, the location of future low-cost housing estates should also consider their closeness to the shopping centres. Public agencies for low-cost housing should pay proper attention to the management of support and public facilities to enhance residential satisfaction of the inhabitants and also adopt a policy to build different sizes of units to cater the needs of residents with large families in order to enhance quality of life of the low-income urban community in the country.
\end{abstract}

(c) 2009 Elsevier Ltd. All rights reserved.

\section{Introduction}

In spite of the Malaysian government's commitment and effort in "providing adequate, affordable and quality houses for all income groups with emphasis on the development of low-andlow medium cost houses" (EPU, 2001, p. 516), two main problems have developed in the housing sector. First, quantitatively the number of housing provided do not meet the demands for the low-income group (Razali, 1993) and second, qualitatively the type of housing has not been satisfactory to the family housing needs, comfort, social, cultural and religious needs (Sulong, 1984; Tan, 1980). The second problem is very important as it influences

\footnotetext{
* Corresponding author. Tel.: +603 6196 5285; fax: +036196 4864.

E-mail address: mohd.mohit@gmail.com (M.A. Mohit).
}

the quality of life and affects the psychosocial aspects of the inhabitants.

Husna and Nurijan (1987) did the first study of residential satisfaction of public low-cost flat dwellers in Kuala Lumpur and found that $41 \%$ of the respondents were dissatisfied with the characteristics in the dwelling unit, $85 \%$ wanted a dining space and $82 \%$ wanted a separate bathroom and toilet in their dwelling units. Recently, the low-cost housing design in Malaysia has undergone changes from the provision of two to three bedrooms with the addition of a dining room, a separate bathroom and a toilet, and a drying area (CIDB, 1998). During the 8th Malaysia Plan (2001-2005), a total of 24,654 units of public low-cost housing, representing $66.2 \%$ of total, have been constructed in Kuala Lumpur by the Ministry of Housing and Local Government by following the new standard (EPU, 2006). However, since then no study has been 
done to assess the residents' satisfaction with the newly constructed public low-cost housing in Malaysia. Therefore, a research need arises to study residential satisfaction of the new public lowcost housing inhabitants whose economic ability for alternative housing is limited. Furthermore, continuous assessment of residential satisfaction of the low-cost housing is essential in order to monitor and guide future public housing policy especially for low-income people in the country.

\section{Objectives and research questions}

Studies of low-cost housing reveal that residential satisfaction depends on a number of factors which need to be carefully studied. This paper intends to investigate those factors and examine their role in the overall satisfaction process. Therefore, the following objectives have been set for the study:

(a) To investigate the level of residential satisfaction/dissatisfaction perceived by the residents of the newly designed public low-cost housing project;

(b) To examine the elements and types of facilities which influence the residential satisfaction level of the inhabitants; and

(c) To determine the key factors/variables whose improvements can enhance housing satisfaction level of the residents.

Research questions

Based on the objectives of the study, a few research questions emerge as stated below:

(a) What are the levels of satisfaction perceived by the residents with the dwelling unit features?

(b) How much the level of satisfaction depends on the dwelling unit support services?

(c) How much the level of satisfaction depends on the provision and quality of public facilities?

(d) How much the level of satisfaction depends upon the social environment of the housing estate?

(e) How much the level of satisfaction is influenced by the provision of neighbourhood facilities?

(f) What are the determining factors that can enhance the housing satisfaction levels of the residents?

The general hypothesis tested in the paper is based on the proposition that residential satisfaction in public low-cost housing is determined by the respondents' perceived levels of satisfaction with objective characteristics like dwelling unit features, dwelling unit support services, public facilities, social environment, and neighbourhood facilities.

\section{Overview of theory and empirical studies}

Research on housing has gone beyond the study of the physical, structural and functional features of one's territorial core called 'house' (Hayward, 1977; Lawrence, 1987). Increasing interest is now shown towards the study of how people think of their housing and how it affects their lives. Therefore, measuring the housing quality has become an important tool and local governments in both UK and USA conduct regular tenant satisfaction surveys to ensure that households are satisfied with the provided housing and its services (Varady \& Carrozza, 2000, p. 799).

Residential satisfaction, defined as the feeling of contentment when one has or achieves what one needs or desires in a house, is an important indicator and planners, architects, developers, and policymakers use it in a number of ways. It has been used as (a) a key predictor of an individual's perceptions of general "quality of life", (b) an indicator of incipient residential mobility and hence has altered housing demands and affected neighbourhood change, (c) an ad hoc evaluative measure for judging the success of developments constructed by private and public sectors, and (d) an assessment tool of residents' perceptions of inadequacies in their current housing environment in order to improve the status quo (Djebuarni \& Al-Abed, 2000).

Theoretical underpinnings on residential satisfaction are based upon the idea that residential satisfaction measures the difference between households' actual and desired/aspired housing and neighbourhood situations (Galster, 1987). Households usually make their judgements about residential conditions based on their needs and aspirations. Satisfaction with households' housing conditions indicates the absence of any complaints and a high degree of congruence between actual and desired situations. On the other hand, incongruence between housing needs and aspirations may lead to dissatisfaction. Rossi (1955) postulates that changing housing needs and aspirations occur as households progress through their life cycle stages leading to residential dissatisfaction at some stage and they respond to this dissatisfaction through migration. Hence, migration is viewed as a process of adjustment with the essential purpose of increasing one's place utility or level of residential satisfaction (Wolpert, 1966).

Morris and Winter $(1975,1978)$ introduced the idea of "housing deficit" and conceptualised housing satisfaction as a dynamic process. In their housing adjustment model of residential mobility, they theorize that households judge their housing conditions according to two types of norms, personal or cultural which may not coincide. An incongruity between the actual housing satisfaction and housing norms results in a housing deficit, which in turn gives rise to residential dissatisfaction, leading to some form of housing adjustments which may be either in situ such as revising their housing needs and aspirations in order to reconcile the incongruity, or improve their housing conditions through remodelling, or else they may move to another place and bring their housing into conformity with their aspirations or needs. However, both migration and in situ adjustments require that the households should have enough information about alternative adaptation opportunities and financial resources. Some empirical studies have demonstrated that housing deficit is a useful concept in explaining residential satisfaction and mobility behaviour (Bruin \& Cook, 1997; Husna \& Nurijan, 1987).

Most empirical studies on residential satisfaction have used either one or a combination of the theoretical frameworks that have been stated above. A host of variables representing housing and neighbourhood characteristics, individuals' socio-demographic attributes as well as their perceptions of housing and neighbourhood conditions have been analysed in previous studies (Lu, 1999). However, the effects of these variables as determinants of residential satisfaction or dissatisfaction tend to vary by housing types, tenure, countries and cultures what stand to indicate that further studies are required until a general theory of residential satisfaction emerges. Lu (1999) has observed that residential satisfaction is a complex construct, affected by a variety of environmental and socio-demographic variables. Mastura, Nor Liza, Osman, and Ramayah (undated) in their cross-section study found that project type, house price and length of residency significantly influence housing satisfaction among the residents of Penang Development Corporation's projects. Ukoha and Beamish (1997) observed that while the residents of public housing in Abuja, Nigeria, were satisfied with neighbourhood facilities, they were dissatisfied with structure types, building features, housing conditions and management.

Husna and Nurijan (1987) found that while the residents of public low-cost housing in Kuala Lumpur, Malaysia, were satisfied with the services rendered by the city hall workers and with the 
neighbourhood factors, a big proportion of them felt dissatisfied with dwelling unit characteristics. Nurizan (1993) reported that the residents of low-cost housing in Johor Bahru were only satisfied with public transport and distance of housing from the city but they were not satisfied with the size, rental and crowding in the house. Djebuarni and Al-Abed (2000) observed that the residents of public lowincome housing in Sana'a, Yemen, attach great importance to the level of satisfaction with their neighbourhoods, particularly, with privacy which reflects the cultural background of Yemeni society. Lane and Kinsey (1980) reported that housing characteristics were more crucial determinants than demographic characteristics of housing occupants. Halimah and Lau (1998) compared the perceived concept of home aspired between Malay and Chinese housewives in low-cost housing in Selangor and found that there were significant differences between the Malays' and Chinese perception of home and housing satisfaction. Ogu (2002) studied urban residential satisfaction of inhabitants living at core, intermediate, suburban, and planned areas of Benin City, Nigeria, and found that while most housing component variables generally contributed positively to residential satisfaction, environmental variables made negative contributions. Salleh (2008) investigated residential satisfaction in two states - Pulau Pinang and Terengganu, and found that the neighbourhood factors as the dominant factors affecting the levels of housing satisfaction in private lowcost housing in Malaysia.

Oh (2000) in her study on housing satisfaction of middle income households in Bandar Baru Bangi, Malaysia, revealed that while the residents were highly satisfied with the space and price of the house owned, but they were not satisfied with the size of kitchen, plumbing, and public facilities such as recreational areas, playground, taxi and bus services in the housing area. Alison, Kearns, and Atkinson (2002), by analysing English Housing data, concluded that although socio-demographic factors were much less important than residential perceptions in helping to predict dissatisfaction, the type of neighbourhood remained a significant independent predictor of dissatisfaction even when residents' views were taken into account. Dwellers in private low-cost housing in and around Bangkok, Thailand, were generally satisfied with their dwelling units than with environmental facilities (Savasdisara, Tips, \& Suwannodom, 1989).

Homeownership or tenure status is a key indicator and determinant of residential satisfaction. Although Husna and Nurijan (1987) did not find any difference between owner and tenant residents of public low-cost housing in Kuala Lumpur, many studies reveal that residential satisfaction is much higher among homeowners than renters (Loo, 1986; Lu, 1999). Elsinga and Hockstra (2005) reported that homeowners in seven out of eight European countries are more satisfied with their housing situation than tenants and only in one country do homeowners and tenants display similar level of satisfaction. Even with similar quality of housing unit, owner-occupiers are likely to be more satisfied than renters, possibly because homeownership gives a sense of 'selfgratification' to owner-occupiers and makes them psychologically proud and satisfied with their dwelling units (Kaitilla, 1993). Barcus (2004) found that tenure shift from renters to owners is the only significant variable in predicting residential satisfaction of American urban-rural migrants; individual migrant characteristics and their motivations offered little explanation for the variation in residential satisfaction. Lu (2002) found similar results when modelling residential satisfaction of intra- and inter-regional migrants. The most likely explanation for this is that renters have less control over their residential environment and in general have a lower housing quality (Loo, 1986).

Residential satisfaction also tends to vary by public and private housing. According to Lu (1999), public renters are more likely to be satisfied with their housing, because, firstly, there tends to be a basic level of amenity, service and maintenance provided for public housing tenants in their dwelling; and secondly, and probably more importantly, the satisfaction with the dwelling is influenced by the large housing estates where dwellings are of similar design, appearance and standard. Hence, public renters are more likely to have very low levels of neighbourhood satisfaction, because of the location and density of the public housing stock. However, Mastura et al. (undated) in their study found that "both groups (owners and renters) have the same level of perception and aspiration on their housing and neighbourhood environment" ( $p$. 16). Baker (2002) has thus observed that location characteristics are important considerations for understanding the formation of residential satisfaction among public housing tenants. While housing is likely to be a source of satisfaction, elements of the neighbourhood such as the level of crime (Mullins, Western, \& Broadbent, 2001) or lack of amenity (Fried, 1982) or industrial development or work place location are likely to be sources of dissatisfaction.

The foregoing review of studies on residential satisfaction indicates that while various housing, neighbourhood and household characteristics determine the level of residential satisfaction, the impacts of these variables as determinants of residential satisfaction or dissatisfaction tend to vary by housing types, tenure, countries and cultures what stand to indicate that researches/studies are required to determine residential satisfaction on case specific situation to guide public policies. In Malaysia, so far studies on public low-cost housing satisfaction were focussed on the older two/single bedroom with single bathroom designed houses. However, the implementation of new high-rise low-cost housing standards (CIDB, 1998) requires that continuous study of housing satisfaction needs to be done to examine the residents' satisfaction level with new housing types. Therefore, this research intends to fill the gap that currently exists in the public low-cost housing in Malaysia.

\section{Conceptual model}

The conceptual model of the paper is based on the notion that residential satisfaction is a composite construct of the indices of satisfaction which respondents perceive with dwelling unit features, dwelling unit support services, public facilities, social environment and neighbourhood facilities. According to Amerigo and Aragones (1997), objective attributes of the residential environment, once they have been evaluated by the individual become subjective giving rise to a certain degree of satisfaction. Subjective attributes are influenced by the subject's socio-demographic and personal characteristics as well as his/her residential quality pattern, a normative element whereby the individual compares his/ her real and ideal residential environment. The model (Fig. 1) shows that the respondents' evaluation of objective attributes of housing through their socio-economic and demographic characteristics becomes subjective attributes which can be captured into five components of housing satisfaction and these five components together form the basis of residential satisfaction of the inhabitants.

\section{Methodology}

Housing differs in its type, size and design, but whatever form it takes, there is a need to measure its quality to ensure that it satisfies the resident's family and cultural norms. Housing quality can be measured through objective and subjective approaches. Objective measurement of housing is widely used and it evaluates the physical characteristics, facilities, services and environment. However, objective assessment is not able to examine and explain the psychosocial aspects of residential satisfaction. Subjective measurement which includes perception, satisfaction, aspiration, and also disappointment is closely related to the psychosocial aspects of a person (Nurizan \& Hashim, 2001). 


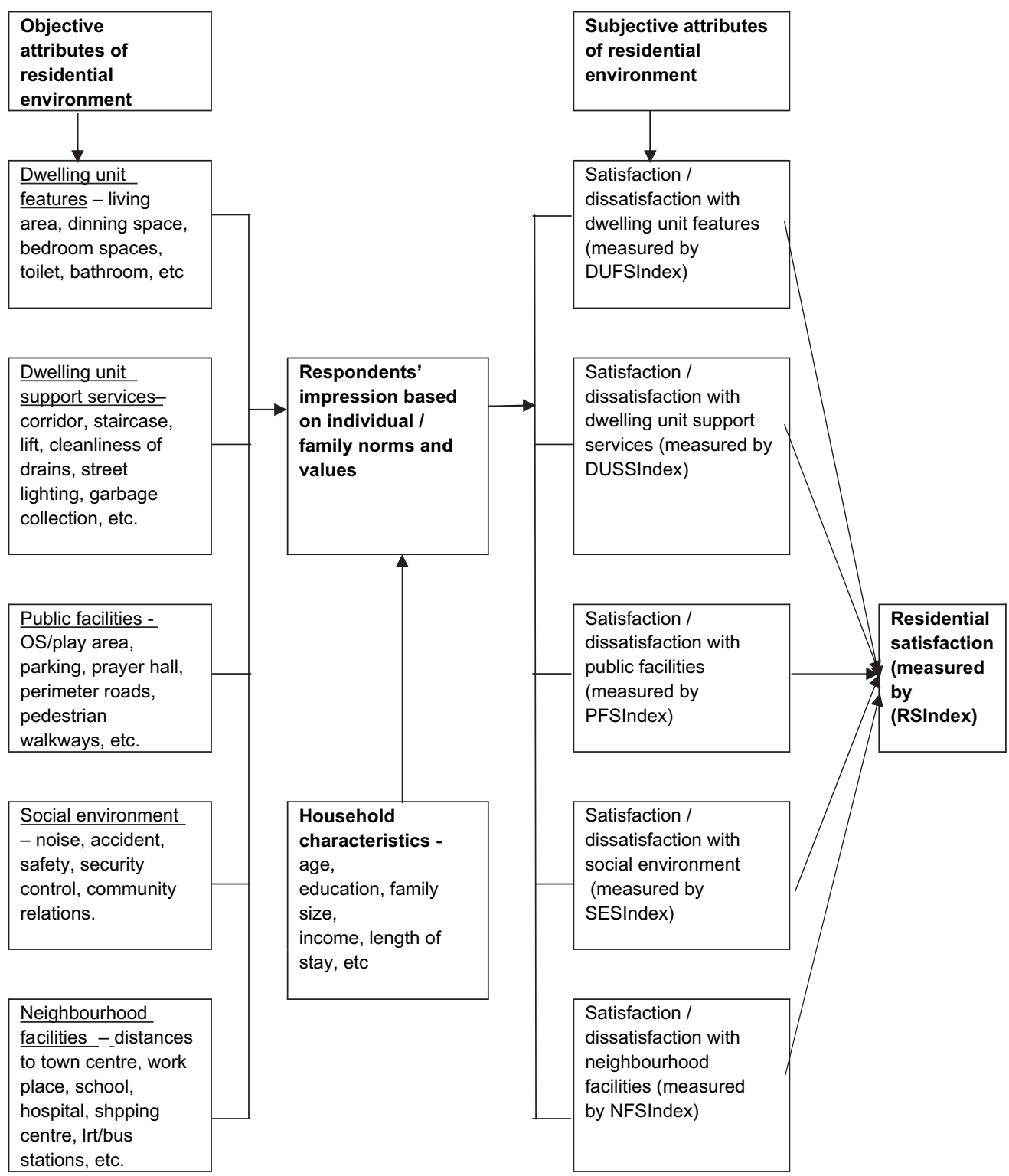

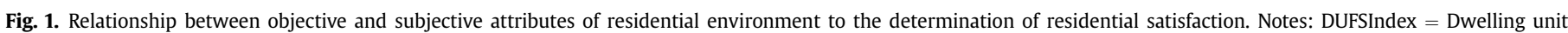

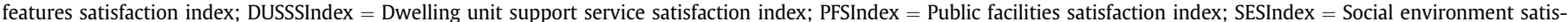
faction index; NFSIndex = Neighbourhood facilities satisfaction index; RSIndex = Residential satisfaction index.

\section{Selection of components and variables for residential satisfaction}

Most residential satisfaction studies have integrated both objective and subjective attributes for the assessment of residential satisfaction. Francescato, Weidemann, and Anderson (1987) contend that satisfaction depends on three elements - the design which includes its space organisation, layout and facilities provided, the management practices (in public housing), and the surrounding social aspects. According to Varady and Carrozza (2000), tenant satisfaction encompasses four distinct types of satisfaction (1) satisfaction with the dwelling unit; (2) satisfaction with the services provided, including repair service; (3) satisfaction with the whole package received for the rent paid - dwelling and service; and (4) satisfaction with the neighbourhood or area. Nurizan and Hashim (2001) reported that besides facilities in the house, basic facilities such as shops, markets, schools, clinic, mailing system, community hall, playground, and others are important to support the daily life of the dwellers, and enhance residents' quality of life. According to Oh (2000), there are three main qualities - (1) the quality of the dwelling; (2) the quality of the close environment; and (3) the quality of the urban site which impact the quality of housing.

Based upon the review of literature on variables that are likely to affect residential satisfaction, the present study considers the "residential satisfaction bundle" to contain two sheltered components - (1) the dwelling unit features with 11 variables; and (2) dwelling unit support services with 8 variables; and three nonsheltered components - (1) public facilities with 9 variables; (2) social environment with 5 variables; and (3) neighbourhood facilities with 12 variables.

\section{Dwelling unit features}

Dwelling unit features refer to the floor plan of internal spaces within the dwelling unit and it includes the living, dining, bedroom, 
kitchen, bathroom, toilet and drying areas, including ventilation of the house.

\section{Dwelling unit support services}

Dwelling unit support services are the external space or support space outside the dwelling unit but within the housing block. The variables included are corridors, staircase, balconies, electricity supply, water supply, sewerage, drainage, telecommunication, lifts and fire fighting system.

\section{Public facilities}

Public facilities play an important role in producing housing quality and hence, these should be incorporated in residential satisfaction. The variables included in this component are - open space, play area, parking, prayer and multi-purpose halls, perimeter roads, pedestrian walkways, public phone, local shops and food stalls.

\section{Social environment}

Housing satisfaction has both design (physical) and social components. Social environment which are likely to impact housing satisfaction include variables such as noise, crime, accidents, security and community relations.

\section{Neighbourhood facilities}

Neighbourhood facilities influence residential satisfaction in many ways, because they refer to the position of the housing area with respect to work place and other facilities such as distances to town centre, school, police station, hospital, market, shopping centres, public library, religious building, LRT, bus and taxi stations.

\section{Sampling design}

In this study, stratified random sampling has been used to select the samples for questionnaire survey. For this purpose, the residents of the public low-cost housing estate were stratified according to blocks, floor levels and races in order to ensure that subgroups in the population are represented in the sample in proportion to their numbers within the population. As a result, a sample of 102 households $(n=102)$ was selected based on Yamane (1967) from a total of 1896 house units $(N=1896)$. The sample size represents $5.3 \%$ of the total housing population with a $90 \%$ confidence level, indicating that in 90 out of 100 repetitions of the survey, the results will not vary more than $\pm 10 \%$. Since there are 6 blocks in the housing area, 17 households represented by 11 (64.7\%) Malays, 3 Chinese (17.6\%), and 3 Indians (17.6\%), respectively, were selected from each block. Respondents were also selected proportionately from the range of floor levels, 1-6 (lower level), 7-12 (middle level) and 13-18 (upper level). The inclusion of ethnicity and floor levels into the sample selection was necessary because some studies have shown that these variables impact residential satisfaction in more than one way.

Structured questionnaire was used to gather data from the respondents, because it has been suggested that when dealing with a population likely to be of the low-income group with low interest and motivation, the structured interview for data collection is the preferable option (Fowler, 1993). The questionnaire form consists of six sections with household and house unit information (section-1); satisfaction with dwelling unit features (section-2); satisfaction with dwelling unit support services (section-3); satisfaction with public facilities (section-4); satisfaction with social environment (section-5); and satisfaction with neighbourhood facilities (section6 ). The level of housing satisfaction has been measured by using a five-point Likert scale - " 1 " for very dissatisfied, " 2 " for dissatisfied, "3" for slightly satisfied, " 4 " for satisfied and " 5 " for very satisfied.

\section{Satisfaction index}

Satisfaction index for a particular housing component has been measured by using Eq. (1):

SIc $=\frac{\sum_{i=1}^{N} y i}{\sum_{i=1}^{N} Y i} \times 100$

where SIC is the satisfaction index of a respondent with the component $c$, of the residential environment, $N$ is the number of variables being scaled under $c, y i$ is the actual score by a respondent on the $i$ th variable and $Y i$ is the maximum possible score that $i$ could have on the scale used.

\section{Residential satisfaction index}

Residential satisfaction index is sum total of the component satisfaction indices (Eq. (2)).

$S I r=\frac{\sum_{i=1}^{N 1} d i+\sum_{i=1}^{N 2} S i+\sum_{i=1}^{N 3} p i+\sum_{i=1}^{N 4} s e i+\sum_{i=1}^{N 5} n i}{\sum_{i=1}^{N 1} D i+\sum_{i=1}^{N 2} S i+\sum_{i=1}^{N 3} P i+\sum_{i=1}^{N 4} S E i+\sum_{i=1}^{N 5} N i} \times 100$

where SIr is the satisfaction index of a respondent with residential environment; $N 1, N 2, N 3, N 4$ and $N 5$ are the number of variables selected for scaling under each component of residential environment, while $d i, s i, p i$, sei and $n i$ represent the actual score of a respondent on the $i$ th variable in the component. $\mathrm{Di}, \mathrm{Si}, \mathrm{Pi}, \mathrm{SEi}$, and $\mathrm{Ni}$ are the maximum possible scores for the $i$ th variable in the dwelling unit features, dwelling unit support services, public facilities, social environment and neighbourhood facilities components, respectively.

\section{Habitability index}

$H I x=\frac{\sum_{i=1}^{N} a y^{\prime} x}{\sum_{i=1}^{N} A y^{\prime} x} \times 100$

$H I x$ represents index of habitability (Ogu, 2002) of variable $x$ and $N$ is the number of respondents (102), while $a y^{\prime} x$ is the actual score on the five-point by the $y$ th respondent on the $x$ th variable. ' $A$ ' represents the maximum possible score that respondent $y^{\prime}$ could give to variable $x$ on the five-point scale.

\section{Public low-cost housing in Kuala Lumpur city and the study area}

Kuala Lumpur City, capital of Malaysia, is a federal territory of the country. The city has a land area of $243.65 \mathrm{~km}^{2}$. It is the hub and nerve centre of the nation with its various political, religious, cultural, economic, banking, financial, commercial, sports and educational activities. As the centre of a developing nation, Kuala Lumpur plays a major role in the urbanisation and development of the country. The city population grew from about 0.32 million in 1957 to almost 1.62 million in 2006, representing a five-fold increase over a 49-year period. This spectacular increase of population has created pressure on the existing housing stocks particularly for the low-income group. In order to tackle this problem, since 1970s, a total of 65,000 units of public low-cost housing were constructed in Kuala Lumpur to accommodate the increasing population ( $\mathrm{KLCH}, 2000) .8 .1 \%$ of the city's residents are 
considered as low-income earners, having monthly household income less than RM1500 (US\$429).

In Malaysia, the low-cost housing development programmes are undertaken both by the public and the private sectors. The public low-cost housing programmes which started from the First Malaysia Plan (1970-1975) are concentrated in the major urban areas like Kuala Lumpur, Georgetown. The main objective of the Public LowCost Housing Programme (PLCH) is to improve the quality of life, eradicate poverty among the low-income group and to resettle the urban squatters. Housing has always been an item of high priority on the City Authority's agenda. The City's strategic vision for A WorldClass City encapsulates the ambition to make Kuala Lumpur a city that will assume a major global and sub-global role for the benefit of all inhabitants, workers, visitors and investors ( $\mathrm{KLCH}, 2008$, p. 1.1). In the Kuala Lumpur Structure Plan-2020, there are about twentythree policies outlined for the housing sector and seven of those policies are related to public low-cost housing (KLCH, 2004: p. 12-912-13). Strategic Direction 6.4 of the Draft Kuala Lumpur City Plan2020 pledges at enhancing the city's public housing to improve living environment $(\mathrm{KLCH}, 2008$, p. 6.8). Therefore, one of the major focuses of the housing sector in Kuala Lumpur is on improving the quality of housing and the housing environment.

The study housing project, Sungai Bonus, is one of the 24 newly designed public low-cost housing projects completed by the Ministry of Housing and Local Government in Kuala Lumpur during the 8th Malaysia Plan. The project is located at a distance of $20 \mathrm{~km}$ far from Kuala Lumpur City centre and it is within the Wangsa Maju-Maluri strategic zone which is one of the six strategic zones of the city. The nearest city centre from the housing estate is the Wangsa Maju satellite centre developed with commercial, business and public rail transit facilities. The housing estate has 1896 units within an area of 12.3 ha with a density of 154 house units per hectare and it is considered as high-density housing. The project is a new generation low-cost high-rise housing built by following the CIS:1998 (CIDB, 1998) according to which each dwelling unit must have a minimum area of $63 \mathrm{~m}^{2}$ with 3 bedrooms, living room, dining room, kitchen, a separate bathroom and toilet and a drying area. The housing project is now managed and maintained by the KLCH (Kuala Lumpur City Hall).

\section{Analysis and findings}

\section{Socio-economic characteristics of the respondents}

Public low-cost housing residents of Sungai Bonus were dominantly male (93\%) compared to female (7\%) (Appendix Table A1). The ethnic composition was $62 \%$ Malays followed by $20 \%$ Chinese and $17 \%$ Indians, respectively. Majority of the respondents (55\%) were between age 41 and 60 , followed by the age group of 31-40 (24.5\%) and the old age people (60+) constituted $15 \%$ in the sample. Although families with 2-5 members were dominant (71\%), $28 \%$ of the respondents had 6-9 persons in their families and $29.4 \%$ families have 2.5 inhabitants in each bedroom. The highest education level of the respondents was upper secondary. Mean monthly income of majority (75.5\%) of respondents was between RM750 (US\$214) and 1500 (US\$429), followed by $14 \%$ whose earnings were more than RM1500 and 11\% earned less than RM750. Majority (46\%) of the respondents' jobs were in the private sector followed by $34 \%$ who had their own businesses and $13 \%$ worked in the Government. A large percentage of respondents (63\%) have stayed in the housing area for 3 years followed by $27 \%$ who stayed for 4 years and only $10 \%$ stayed for 2 years. While $6 \%$ of the respondents did not own any transport, a large percentage (45\%) own car followed by $32 \%$ who own motorcycle and $17 \%$ own both car and motorcycle. $30.4 \%$ of the respondents had working wives.

\section{Satisfaction with residential environment}

Respondents' levels of satisfaction with residential environment consisting of 45 variables presented in Appendix Table A2 reveal that the residents of low-cost housing perceived moderate level of satisfaction (65.9) with their overall housing situation. Satisfaction index with dwelling unit support services is the highest (69.3), followed by public facilities (68.2), dwelling unit features (67.1), neighbourhood facilities (64.5), and social environment (60.4), respectively. The percentage of respondents with moderate level of satisfaction is large (99.0\%) in neighbourhood facilities, followed by $96.1 \%$ in dwelling support services, $92.2 \%$ in public facilities, $76.5 \%$ in dwelling unit features and $62.7 \%$ in social environment. This finding tends to support Lu's (1999) proposition that public housing estates are better supplied with common/public facilities to satisfy their residents. Respondents with low level of satisfaction are high $(37.3 \%)$ in social environment component followed by dwelling unit features component (22.5\%) and public facilities component (8.7). Fig. 2 shows that while percentage of respondents with low satisfaction are relatively high in social environment followed by dwelling unit features and public facilities; for other components, the percentage of respondents with low satisfaction are negligible. This finding supports Husna and Nurijan's (1987) study about public low-cost housing in Kuala Lumpur, Nurizan's (1993) study of low-cost housing in Johor, Malaysia, and Ukoha and Beamish's (1997) study of public housing in Abuja, Nigeria. But the finding is somehow tends to be contrary to other studies (Lu, 1999; Ogu, 2002; Salleh, 2008; Savasdisara et al., 1989).

The habitability indices (Appendix Table A2) show that the respondents revealed very low level of satisfaction with dry area and kitchen, with significant correlation coefficients $(r)$ of 0.43 and 0.42 , respectively, with dwelling unit factor, followed by distances to LRT station and hospital, with negligible correlations with the neighbourhood facilities factor/component. Low level of satisfaction is perceived by the residents with distances to public library, market and work place, with correlation coefficient $(r)$ values of none, 0.37 and 0.57 , respectively, with the neighbourhood factor. For social environment low level of residents' satisfaction was perceived with security control, crime situation with significant positive correlations of 0.65 and 0.38 with the factor. Satisfaction with open space/play area shows low habitability with significant correlation of 0.37 with social environment factor.

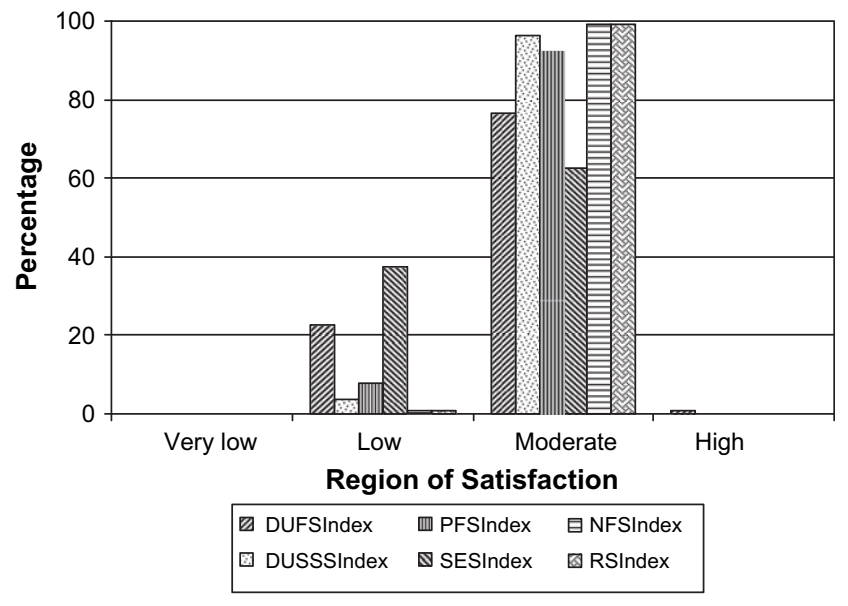

Fig. 2. Distribution of different indices of residential satisfaction. 
Relationships between residential satisfaction components and socio-economic characteristics of respondents

Pearson's correlation coefficient ( $r$ ) between residential satisfaction component indices and residents' socio-economic characteristics (Appendix Table A3) shows that residential satisfaction index is highly positively correlated with dwelling unit features index followed by social environment, dwelling unit support services and public facilities indices, with neighbourhood facilities having a lower degree of positive correlation with residential satisfaction. Inter-component correlation shows that there are low positive correlations of dwelling unit features with neighbourhood facilities, and dwelling unit support services with social environment. Residential satisfaction of the respondents declines with the increase in family sizes and ages, while it tends to increase with floor levels. Satisfaction with dwelling unit features tends to be positively correlated with race or ethnicity, while the same tends to decline highly with increase in family sizes. Housing satisfaction with support services is also positively correlated with residents' floor levels. Respondents' length of residency and employment type are positively correlated with satisfaction with public facilities which are, however, negatively associated with respondents' previous housing types. Social environment satisfaction index shows negative correlations with respondents' age, and working wives, while the same component has positive correlations with floor levels. It, thus, appears that residents' socio-economic attributes such as age, family size, working wives, previous residence are negatively related to residential satisfaction, while race, employment, floor level and length of residency have positive correlation with residential satisfaction.

\section{Multivariate analysis}

Multiple Linear Regression (MLR) analysis is a method for measuring the simultaneous effects of two or more predictor (independent) variables to explain variations in the dependent variable. An MLR model has been estimated to determine the best linear combination of 45 residential satisfaction variables for predicting (overall) residential satisfaction by using stepwise method. The exercise resulted to the selection of ten variables - satisfactions with bedroom-3, security control, perimeter road, garbage house cleanliness, socket points, dinning space, dry area, garbage collection, bedroom-1 and distance to shopping centres, as predictor variables to determine residential satisfaction of Sungai Bonus lowcost housing inhabitants. The combination of predictor variables significantly predicted residential satisfaction of public low-cost housing, with $F(10,84)=30.337, p<.001$, with all ten variables significantly contributing to the prediction. The beta weights presented in Appendix Table A4 suggest that satisfactions with security control, perimeter road, cleanliness of garbage house, and garbage collection contribute most to predicting residential satisfaction, followed by dry area, bedroom-1, dinning space, socket points, bedroom-3 and distance to shopping centre, which contribute moderately to residential satisfaction of the public lowcost housing. The adjusted $R^{2}$ value $(0.757)$ of the model indicates that $76 \%$ of the variance in residential satisfaction is explained by the model. The tolerance values of the coefficients of predictor variables are well over $0.24\left(1-\mathrm{R}^{2}\right)$ and this indicates absence of multicollinearity between the predictor variables of the model.

\section{Conclusions}

In general, the residents of newly designed Sungai Bonus public low-cost housing are moderately satisfied with their residential environment. However, the percentage of residents moderately satisfied is high with neighbourhood facilities followed by support services, and public facilities, than with dwelling unit features and social environment, which have got higher percentage of respondents with low level of satisfaction. Correlation between cross-component satisfaction indices is low, whereas residential satisfaction index has high positive correlations with dwelling unit features, social environment, support services and public facilities, but it has low positive correlation with neighbourhood facilities. Socio-economic variables such as age, family size, working wives, previous residence are negatively correlated with residential satisfaction, whereas race, employment type, floor level and length of residency are positively correlated with residential satisfaction. The MLR model, which provides $76 \%$ explanation to determine residential satisfaction, is based on ten predictor variables, of which the management-related four variables such as satisfactions with security control, perimeter road, cleanliness of garbage house, and garbage collection had high beta coefficients with housing satisfaction, compared to the six variables such as satisfactions with dry area, bedroom-1, dinning space, socket points, bedroom-3 and distance to shopping centre, which had moderate beta coefficients and four of these variables belong to the dwelling unit features component except the last one which belongs to neighbourhood facilities component.

\section{Policy implications}

The policy implications of the study suggest that residential satisfaction of Sungai Bonus public low-cost housing can be enhanced through improving the management of security control, perimeter roads, cleanliness of garbage house and garbage collection - all these predictors have high beta coefficient values. Local authority $(\mathrm{KLCH})$ which is responsible for the management of public low-cost housing in Kuala Lumpur can adopt proper management measures in order to improve the residents' housing environment. Further studies are required to determine a suitable management model which should involve both the local authority and the residents. The dwelling unit related predictor variables with moderate beta values such as dry area, bedroom- 1 space, dinning space, socket points and bedroom-3 space need to be upgraded through improved housing design in order to enhance residential satisfaction. It appears that of the 11 dwelling unit features, 5 require improvements in design, implying that the size of existing low-cost units is not appropriate to a significant percentage (29.4\% from Appendix Table A1) of the target group with large $(6+)$ size families and with high bedroom occupancy rates (2.5) and they are the one who possibly have expressed dissatisfaction with a large number of dwelling unit variables. The negative correlations $(r)$ between family size and housing satisfaction both overall $(-0.45)$ and dwelling unit features $(-0.81)$ (Appendix Table A3) provide further support to this observation. The policy implication of this observation indicates that the future design of low-cost housing should be responsive to the five dwelling features by providing larger spaces and this will result in an overall increase in the size of housing unit, cost of construction and so the rental of public low-cost housing. Another policy option is that government can build at least $30 \%$ larger units within a lowcost housing estate to cater the needs of the residents with large families $(6+)$. The location of future low-cost housing projects should also consider their closeness to the shopping centres as the MLR model indicates. It is thus recommended that public agencies for low-cost housing should pay proper attention to the management of support and public facilities to enhance residential satisfaction of the inhabitants and also adopt a policy to build different sizes of units to cater the needs of the residents with large families in order to enhance quality of life of the low-income urban community in the country. 
Appendix

Table A1

Respondents' demographic and socio-economic characteristics.

\begin{tabular}{|c|c|c|}
\hline Socio-demographic characteristics & Frequency $(n=102)$ & Percent \\
\hline \multicolumn{3}{|l|}{ Gender } \\
\hline Male & 95 & 93.1 \\
\hline Female & 7 & 6.9 \\
\hline \multicolumn{3}{|l|}{ Race } \\
\hline Malay & 63 & 61.8 \\
\hline Chinese & 20 & 19.6 \\
\hline Indian & 17 & 16.7 \\
\hline Others & 2 & 2.0 \\
\hline \multicolumn{3}{|l|}{ Age } \\
\hline $25-30$ & 5 & 4.9 \\
\hline $31-40$ & 25 & 24.5 \\
\hline $41-60$ & 57 & 55.9 \\
\hline$>60$ & 15 & 14.7 \\
\hline \multicolumn{3}{|l|}{ Family size/persons per bedroom } \\
\hline 2-5 persons/persons per bedroom & $72 / 1.2$ & 70.6 \\
\hline 6-9 persons/persons per bedroom & $29 / 2.5$ & 28.4 \\
\hline $10-11$ persons/persons per bedroom & $1 / 3.5$ & 1.0 \\
\hline Persons per bedroom (average) & 1.6 & - \\
\hline \multicolumn{3}{|l|}{ Educational level } \\
\hline No formal education & 1 & 1.0 \\
\hline Primary & 9 & 8.8 \\
\hline Lower secondary & 38 & 37.3 \\
\hline Upper secondary & 53 & 52.0 \\
\hline University/college/institute & 1 & 1.0 \\
\hline \multicolumn{3}{|l|}{ Monthly family income } \\
\hline$<$ RM750 & 11 & 10.8 \\
\hline RM750-RM1000 & 25 & 24.5 \\
\hline RM1000-RM1200 & 25 & 24.5 \\
\hline RM1200-RM1500 & 27 & 26.5 \\
\hline$>$ RM1500 & 14 & 13.7 \\
\hline \multicolumn{3}{|l|}{ Employment sector } \\
\hline Government & 13 & 12.7 \\
\hline Private & 47 & 46.1 \\
\hline Own business & 35 & 34.3 \\
\hline Others & 7 & 6.9 \\
\hline \multicolumn{3}{|l|}{ Length of residency } \\
\hline 2 years & 10 & 9.8 \\
\hline 3 years & 64 & 62.7 \\
\hline 4 years & 28 & 27.5 \\
\hline Total & 102 & 100.0 \\
\hline \multicolumn{3}{|l|}{ Vehicle owned } \\
\hline Motorcycle & 33 & 32.4 \\
\hline Car & 46 & 45.1 \\
\hline Car and motorcycle & 17 & 16.7 \\
\hline None & 6 & 5.9 \\
\hline \multicolumn{3}{|l|}{ Working wives } \\
\hline Yes & 31 & 30.4 \\
\hline No & 71 & 69.6 \\
\hline
\end{tabular}

Source: Field Survey, 2007.

Table A2

Distribution of residential satisfaction variables by regime of satisfaction habitability indices and Pearson $(r)$.

\begin{tabular}{llllllrl}
\hline Satisfaction with & $\begin{array}{l}\text { Very } \\
\text { low }\end{array}$ & Low & $\begin{array}{l}\text { Mode- } \\
\text { rate }\end{array}$ & High & $\begin{array}{l}\text { Habita- } \\
\text { bility } \\
\text { Index }\end{array}$ & SD & $\begin{array}{l}\text { Pearson } \\
(r)\end{array}$ \\
\hline Living area & - & - & 6.9 & 93.1 & 82.3 & 10.0 & $0.31^{* *}$ \\
Dinning space & - & - & 29.4 & 70.6 & 76.5 & 12.4 & $0.59^{* *}$ \\
Kitchen space & 32.3 & 50.0 & 15.7 & 2.0 & 37.4 & 14.8 & $0.42^{* *}$ \\
Bedroom-1 & - & - & 7.8 & 92.2 & 82.0 & 9.9 & $0.31^{* *}$ \\
Bedroom-2 & - & - & 26.5 & 73.5 & 75.7 & 10.4 & $0.81^{* *}$ \\
Bedroom-3 & 12.8 & 21.6 & 17.6 & 48.0 & 60.2 & 22.1 & $0.82^{* *}$ \\
Toilet & - & 5.9 & 23.5 & 70.6 & 72.1 & 11.8 & $0.84^{* *}$ \\
Bathroom & - & 5.9 & 22.5 & 71.6 & 73.1 & 11.8 & $0.82^{* *}$ \\
Dry area & 33.3 & 58.8 & 7.8 & - & 34.9 & 11.8 & $0.43^{* *}$ \\
Socket & - & 1.0 & 96.1 & 2.9 & 71.3 & 4.1 & $0.61^{* *}$ \\
Ventilation & - & - & 92.2 & 7.8 & 71.0 & 4.9 & $0.46^{* *}$ \\
$\quad$ of House & & & & & & &
\end{tabular}

Table A2 (continued)

\begin{tabular}{|c|c|c|c|c|c|c|c|}
\hline Satisfaction with & $\begin{array}{l}\text { Very } \\
\text { low }\end{array}$ & Low & $\begin{array}{l}\text { Mode- } \\
\text { rate }\end{array}$ & High & $\begin{array}{l}\text { Habita- } \\
\text { bility } \\
\text { Index }\end{array}$ & SD & $\begin{array}{l}\text { Pearson } \\
(r)\end{array}$ \\
\hline $\begin{array}{l}\text { Dwelling Unit } \\
\text { Features (11) }\end{array}$ & 0.0 & 22.5 & 76.5 & 1.0 & 67.1 & 6.9 & 1.00 \\
\hline Corridor & - & 30.4 & 25.5 & 44.1 & 62.7 & 17.1 & $0.38^{* *}$ \\
\hline Staircase & - & - & 2.9 & 97.1 & 79.4 & 3.4 & - \\
\hline Lift & - & 3.9 & 91.2 & 4.9 & 67.6 & 6.3 & - \\
\hline Fire fighting & - & - & - & 100.0 & 83.3 & 7.5 & - \\
\hline $\begin{array}{c}\text { Cleanliness } \\
\text { of drain }\end{array}$ & - & 16.7 & 17.6 & 65.7 & 69.8 & 15.3 & $0.39^{* *}$ \\
\hline Street lighting & - & 14.7 & 20.6 & 64.7 & 70.0 & 14.8 & $0.51^{* *}$ \\
\hline $\begin{array}{l}\text { Garbage } \\
\text { collection }\end{array}$ & - & 24.5 & 27.5 & 48.0 & 64.7 & 16.4 & $0.50^{* *}$ \\
\hline $\begin{array}{l}\text { Cleanliness } \\
\text { of garbage } \\
\text { house }\end{array}$ & 8.8 & 36.3 & 17.6 & 37.3 & 56.7 & 20.7 & $0.50^{* *}$ \\
\hline $\begin{array}{l}\text { Dwelling Unit } \\
\text { Support } \\
\text { Services (08) }\end{array}$ & - & 3.9 & 96.1 & - & 69.3 & 5.0 & 1.00 \\
\hline OS/Play area & 4.0 & 44.5 & 50.5 & 1.0 & 57.5 & 10.1 & $0.37^{* *}$ \\
\hline $\begin{array}{l}\text { Car/Motorcycle } \\
\text { parking } \\
(n=96)\end{array}$ & - & 19.8 & 59.4 & 20.8 & 67.5 & 10.4 & $0.57^{* *}$ \\
\hline Prayer hall & - & 1.6 & 96.8 & 1.6 & 70.0 & 5.0 & - \\
\hline $\begin{array}{l}\text { Multi-purpose } \\
\text { hall }\end{array}$ & - & 13.2 & 85.3 & 1.5 & 63.1 & 4.6 & - \\
\hline Perimeter road & - & 3.9 & 34.3 & 61.8 & 75.4 & 8.9 & $0.77^{* *}$ \\
\hline $\begin{array}{l}\text { Pedestrian } \\
\text { Walkways }\end{array}$ & - & - & 20.6 & 79.4 & 71.1 & 3.8 & $0.61^{* *}$ \\
\hline Public phone & 8.8 & 18.7 & 25.4 & 47.1 & 65.5 & 17.1 & $0.77^{* *}$ \\
\hline Local shops & - & 38.2 & 42.7 & 19.1 & 62.7 & 9.7 & $0.52^{* *}$ \\
\hline Food stalls & - & 1.5 & 33.8 & 54.7 & 76.6 & 5.8 & $0.24^{*}$ \\
\hline $\begin{array}{l}\text { Public Facilities } \\
\quad(09)\end{array}$ & - & 7.8 & 92.2 & - & 68.2 & 5.17 & 1.00 \\
\hline Noise level & - & 15.7 & 42.2 & 42.2 & 65.3 & 14.3 & $0.44^{* *}$ \\
\hline Accident situation & - & - & 9.8 & 90.2 & 78.0 & 6.0 & $0.32^{* *}$ \\
\hline Crime situation & 14.6 & 26.5 & 47.1 & 26.5 & 40.0 & 14.6 & $0.38^{* *}$ \\
\hline Security control & 16.7 & 31.4 & 53.9 & 6.9 & 38.3 & 16.7 & $0.65^{* *}$ \\
\hline $\begin{array}{l}\text { Community } \\
\text { relations }\end{array}$ & - & - & 18.6 & 60.8 & 80.4 & 12.5 & $0.33^{* *}$ \\
\hline $\begin{array}{l}\text { Social } \\
\text { Environment } \\
(05)\end{array}$ & - & 37.3 & 62.7 & - & 60.4 & 5.8 & 1.00 \\
\hline $\begin{array}{l}\text { Distance to } \\
\text { nearest town } \\
\text { centre }\end{array}$ & - & - & - & 100.0 & 80.8 & 3.9 & $0.47^{* *}$ \\
\hline $\begin{array}{l}\text { Distance to Work } \\
\text { place }\end{array}$ & 3.9 & 51.0 & 4.9 & 40.2 & 57.4 & 20.8 & $0.57^{* *}$ \\
\hline Distance to school & - & - & - & 100.0 & 81.0 & 4.3 & $0.36^{* *}$ \\
\hline $\begin{array}{l}\text { Distance to Police } \\
\text { Station }\end{array}$ & - & - & 14.7 & 85.3 & 77.4 & 7.8 & $0.24^{*}$ \\
\hline $\begin{array}{l}\text { Distance to } \\
\text { Hospital }\end{array}$ & 20.6 & 71.6 & 7.8 & - & 37.4 & 10.4 & $0.25^{*}$ \\
\hline $\begin{array}{l}\text { Distance to } \\
\text { Shopping } \\
\text { centre }\end{array}$ & - & 7.8 & 11.8 & 80.4 & 74.7 & 12.2 & $0.42^{* *}$ \\
\hline $\begin{array}{c}\text { Distance to } \\
\text { Market }\end{array}$ & 2.0 & 62.7 & - & 35.3 & 54.5 & 21.1 & $0.37^{* *}$ \\
\hline $\begin{array}{l}\text { Distance to Public } \\
\text { Library }\end{array}$ & 12.7 & 71.6 & 15.7 & - & 40.6 & 6.7 & - \\
\hline $\begin{array}{l}\text { Distance to } \\
\text { Religious } \\
\text { building }\end{array}$ & - & 14.7 & 2.0 & 83.3 & 74.1 & 14.8 & $0.20^{*}$ \\
\hline $\begin{array}{l}\text { Distance to LRT } \\
\text { Station }\end{array}$ & 20.6 & 79.4 & - & - & 35.9 & 8.1 & - \\
\hline $\begin{array}{l}\text { Distance to Bus } \\
\text { station }\end{array}$ & - & - & 6.9 & 93.1 & 78.6 & 5.1 & - \\
\hline $\begin{array}{l}\text { Distance to fire } \\
\text { station }\end{array}$ & - & - & - & 100.0 & 82.1 & 6.2 & $0.24^{*}$ \\
\hline $\begin{array}{r}\text { Neighbourhood } \\
\text { Facilities (12) }\end{array}$ & - & 1.0 & 99.0 & - & 64.5 & 3.1 & 1.00 \\
\hline $\begin{array}{l}\text { Residential } \\
\text { Satisfaction } \\
\text { (45) }\end{array}$ & - & 1.0 & 99.0 & - & 65.9 & 2.6 & - \\
\hline
\end{tabular}

Source: Field Survey, 2007.

Notes: Regime of satisfaction: Very low $=20-39 ;$ Low $=40-59$; Moderate $=60-79$; High $=80-100$.

${ }^{* *}$ significant at .01 level, *significant at .05 level. 
Table A3

Pearson's correlation coefficient $(r)$ matrix between residential satisfaction components and socio-economic characteristics of respondents.

\begin{tabular}{|c|c|c|c|c|c|c|c|c|c|c|c|c|c|}
\hline Variables & DUFSIndex & DUSSSIndex & PFSIndex & SESIndex & NFSIndex & R_Age & R_Race & R_Emp & W_wives & F_size & F_level & R_Lstay & P_Htype \\
\hline$\overline{\text { DUFSIndex }}$ & & & & & $0.20^{*}$ & & $0.21^{*}$ & & & $-0.81^{* *}$ & & & \\
\hline DUSSSIndex & & & & $0.20^{*}$ & & & & & & & $0.44^{* *}$ & & \\
\hline PFSIndex & & & & & & & & $0.23^{*}$ & & & & $.36^{* *}$ & $-0.20^{*}$ \\
\hline SESIndex & & $0.20^{*}$ & & & & $-0.31^{* *}$ & & & $-0.22^{*}$ & & $0.42^{* *}$ & & \\
\hline NFSIndex & $0.20^{*}$ & & & & & & & & & & & & \\
\hline RSIndex & $0.59^{* *}$ & $0.48^{* *}$ & $0.47^{* *}$ & $0.55^{* *}$ & $0.27^{* *}$ & $-0.24^{*}$ & & & & $-0.45^{* *}$ & $0.32^{* *}$ & & \\
\hline
\end{tabular}

Source: Field Survey, 2008.

Notes: ** significant at .01 level, *significant at .05 level.

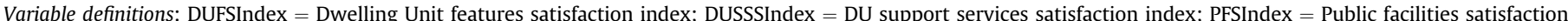

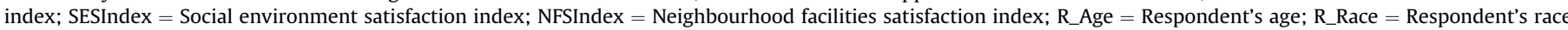

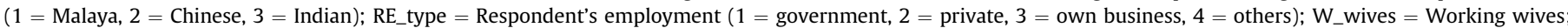

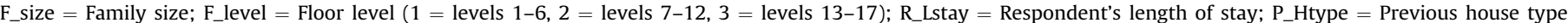
( 1 = squatters, $2=$ long house, $3=$ village house, $4=$ others); RSIndex = Residential satisfaction index.

Table A4

Regression analysis of residential satisfaction index with residential environment variables.

\begin{tabular}{|c|c|c|c|c|c|}
\hline \multirow[t]{3}{*}{$R=.885$} & \multirow{2}{*}{\multicolumn{2}{|c|}{$\begin{array}{l}33 \begin{array}{l}\text { Adjusted } \\
R^{2}=.757\end{array} \\
\text { Unstandardized } \\
\text { Coefficients }\end{array}$}} & \multicolumn{2}{|c|}{$\begin{array}{l}\text { Std Error of } \\
\text { Estimate } 1.26345\end{array}$} & Significance .048 \\
\hline & & & $\begin{array}{l}\text { Standardized } \\
\text { Coefficients }\end{array}$ & t-value & Significance \\
\hline & B & Std. Error & Beta & & \\
\hline Constant & 35.946 & 2.946 & & 12.108 & .000 \\
\hline Bdrm-3 & .016 & .008 & .137 & 2.050 & .048 \\
\hline Sec_Control & .051 & .008 & .341 & 6.429 & .000 \\
\hline Peri_Road & .085 & .015 & .298 & 5.549 & .000 \\
\hline GarH_clean & .036 & .007 & .295 & 5.524 & .000 \\
\hline Socket_Points & .104 & .039 & .169 & 2.644 & .010 \\
\hline Din_Space & .034 & .012 & .170 & 2.934 & .004 \\
\hline Dry_Area & .038 & .011 & .176 & 3.312 & .001 \\
\hline Garb_Collection & .029 & .008 & .180 & 3.374 & .001 \\
\hline Bdrm-1 & .043 & .014 & .171 & 3.212 & .002 \\
\hline Dist_ShopCentre & .024 & .012 & .118 & 2.008 & .048 \\
\hline
\end{tabular}

DEPENDENT VARIABLE $=$ RESIDENTIAL SATISFACTION INDEX (RSIndex).

Variable definition: Bdrm-3 = Satisfaction with Bedroom-3; Sec_Control = Satisfaction with Security control; Peri_Road = Satisfaction with Perimeter road; GarH_clean = Garbage house cleanliness; Socket_Points = Socket points in the house; Din_Space $=$ Dinning space (area); Dry_Area $=$ Cloth drying area; Garb_Collection $=$ Satisfaction with garbage collection; Bdrm-1 = Satisfaction with Bedroom-1; Dist_ShopCentre = Distance to Shopping Centre.

\section{References}

Alison, P., Kearns, A., \& Atkinson, R. (2002). What makes people dissatisfied with their neighbourhoods? Urban Studies, 39(13), 2413-2438.

Amerigo, M., \& Aragones, J. M. (1997). A theoretical and methodological approach to the study of residential satisfaction. Journal of Environmental Psychology, 17, 47-57.

Baker, E. (2002). Public housing tenant relocation - Residential mobility, satisfaction and the development of a tenant's spatial decision support system. Unpublished Doctor of Philosophy thesis, Australia: The University of Adelaide.

Barcus, H. R. (2004). Urban-rural migration in the USA: an analysis of residential satisfaction. Regional Studies, 38(6), 643-657.

Bruin, M. J., \& Cook, C. C. (1997). Understanding constraints and residential satisfaction among low-income single-parent families. Environment and Behavior, 23(5), 531-552.

Construction Industry Development Board (CIDB). (1998). National housing standard for high-rise low cost housing - Construction Industry Standard (CIS-2)-1998. Kuala Lumpur: CIDB.

Djebuarni, R., \& Al-Abed, A. (2000). Satisfaction level with neighbourhood in lowincome public housing in Yemen. Property Management, 18(4), 230-242.

Economic Planning Unit (EPU). (2001). Eighth Malaysia plan (2001-2005). Putrajaya: Prime Minister's Department.

Economic Planning Unit (EPU). (2006). Ninth Malaysia plan (2006-2010). Putrajaya: Prime Minister's Department.

Elsinga, M., \& Hockstra, J. (2005). Homeownership and housing satisfaction. Journal of Housing and the Built Environment, 20, 301-324.

Fowler, F. (1993). Survey research methods. Newbury Park, CA: Sage Publications.
Francescato, G., Weidemann, S., \& Anderson, J. R. (1987). Residential satisfaction: its uses and limitations in housing research. In W. V. Vliet, H. Choldin W. Michelson, \& P. Popene (Eds.), Housing and neighbourhood: Theoretical and empirical contributions (pp. 43-57). Westport, CT: Greenwood Press.

Fried, M. (1982). Residential attachment: sources of residential and community satisfaction. Journal of Social Issues, 38(3), 107-119.

Galster, G. C. (1987). Identifying the correlates of dwelling satisfaction: an empirical critique. Environment and Behavior, 19(5), 539-568.

Halimah, A., \& Lau, Y. C. (1998). Concept of housing satisfaction perceived by housewives living in low-cost housing. Malaysia Journal of Consumer and Family Economics, 1, 145-156.

Hayward, D. G. (1977). Housing research and the concept of home. Housing Educator Journal, 4(3), 110-121.

Husna, S., \& Nurijan, Y. (1987). Housing provision and satisfaction of low-income households in Kuala Lumpur. Habitat International, 11(4), 27-38.

Kaitilla, S. (1993). Satisfaction with public housing in Papua New Guinea. Environment and Behavior, 25(4), 514-545.

KLCH (Kuala Lumpur City Hall). (2000). Buletin Jabatan Pengurusan Perumahan. Kuala Lumpur: DBKL.

KLCH (Kuala Lumpur City Hall). (2004). Kuala Lumpur structure plan 2020. Kuala Lumpur: Percetakan Nasional Malaysia Berhad.

KLCH (Kuala Lumpur City Hall). (2008). Draft Kuala Lumpur city plan 2020. Kuala Lumpur: Percetakan Nasional Malaysia Berhad.

Lane, S., \& Kinsey, J. (1980). Housing tenure and housing satisfaction. Journal of Consumer Affairs, 14, 341-365.

Lawrence, R. J. (1987). What makes a house a home? Environment and Behaviour, 19(2), 154-167.

Loo, C. (1986). Neighborhood satisfaction and safety: a study of low-income ethnic area. Environment and Behavior, 18(1), 109-131.

Lu, M. (1999). Determinants of residential satisfaction: ordered logit vs regression models. Growth and Change, 30, 264-287.

Lu, M. (2002). Are pastures greener? Residential consequences of migration. International Journal of Population Geography, 8, 201-216.

Mastura, J., Nor Liza, H., Osman, M., \& Ramayah, T. (undated). The determinants of housing satisfaction level: a study of residential development project by Penang Development Corporation. Malaysia: Universiti Sains Malaysia.

Morris, E. W., \& Winter, M. (1975). A theory of family housing adjustment. Journal of Marriage and the Family, 37, 79-88.

Morris, E. W., \& Winter, M. (1978). Housing, family and society. New York: John Wiley and Sons.

Mullins, P. J., Western, \& Broadbent, B. (2001). The links between housing and nine key socio cultural factors: a review of evidence. Position paper. Australia: Australian Housing and Urban Research Institute (AHURI).

Nurizan, Y. (1993). Space deficit in low-cost household of Peninsular Malaysia. Kajian Malaysia, 11(1), 56-75.

Nurizan, Y., \& Hashim, A. H. (2001). Perumahan dan Kediaman. Malaysia: Universiti Putra Malaysia.

Ogu, V. I. (2002). Urban residential satisfaction and the planning implications in a developing World context: the example of Benin City, Nigeria. International Planning Studies, 7(1), 37-53.

Oh, L.S. (2000). Housing satisfaction of middle income households in Bandar Baru Bangi, Selangor. Dissertation, Universiti Pertanian Malaysia.

Razali, A. (1993). Transit house: privatisation of low-cost housing in peninsular Malaysia. In International seminar and exhibition on low-cost housing. Penang: Universiti Sains Malaysia.

Rossi, P. H. (1955). Why families move. Glencoe, IL: The Free Press.

Salleh, A. G. (2008). Neighbourhood factors in private low-cost housing in Malaysia. Habitat International, 32(4), 485-494.

Savasdisara, T., Tips, W. E. J., \& Suwannodom, S. (1989). Residential satisfaction in private estates in Bangkok: a comparison of low-cost housing estates and determinant factors. Habitat International, 13(1), 65-73.

Sulong, M. (1984). Perumahan Awam Kos Rendah di Terengganu: Isu, Masalah dan Penerimaan Masyarakat. Malaysia: Universiti Kebangsaan Malaysia. 
Tan, S. H. (1980). Factors influencing the location, layout and scale of low-cost housing in Malaysia. In S. H. Tan, \& H. Sendut (Eds.), Public and private housing in Malaysia. Kuala Lumpur: Heinemann Educational Books (Asia) Ltd.

Ukoha, O. M., \& Beamish, J. O. (1997). Assessment of resident's satisfaction with public housing in Abuja, Nigeria. Habitat International, 21(4), 445-460.
Varady, D. P., \& Carrozza, M. A. (2000). Towards a better way to measure customer satisfaction levels in public housing: a report from Cincinnati. Housing Studies, 15(6), 797-825.

Wolpert, J. (1966). Migration as an adjustment to environmental stress. Journal of Social Issues, 22, 91-102.

Yamane, T. (1967). Statistics: An introductory analysis (2nd ed.). New York: Harper and Row. 